\title{
-Hydroxybutyrate dehydrogenase decorated MXene nanosheets for the amperometric determination of -hydroxybutyrate
}

Koyappayil, Aneesh; Chavan, Sachin Ganpat; Mohammadniaei, Mohsen; Go, Anna; Hwang, Sei Young; Lee, Min Ho

Published in:

Microchimica Acta

Link to article, DOI:

10.1007/s00604-020-04258-y

Publication date:

2020

Document Version

Peer reviewed version

Link back to DTU Orbit

Citation (APA):

Koyappayil, A., Chavan, S. G., Mohammadniaei, M., Go, A., Hwang, S. Y., \& Lee, M. H. (2020). -

Hydroxybutyrate dehydrogenase decorated MXene nanosheets for the amperometric determination of hydroxybutyrate. Microchimica Acta, 187(5), [277]. https://doi.org/10.1007/s00604-020-04258-y

\section{General rights}

Copyright and moral rights for the publications made accessible in the public portal are retained by the authors and/or other copyright owners and it is a condition of accessing publications that users recognise and abide by the legal requirements associated with these rights.

- Users may download and print one copy of any publication from the public portal for the purpose of private study or research.

- You may not further distribute the material or use it for any profit-making activity or commercial gain

- You may freely distribute the URL identifying the publication in the public portal 


\title{
$\beta$-hydroxybutyrate dehydrogenase decorated MXene nanosheets for the amperometric determination of $\beta$-hydroxybutyrate
}

\author{
Aneesh Koyappayil", Sachin Ganpat Chavan*, Mohsen Mohammadniaei*, Anna Go*, Sei Young Hwang*, \\ Min-Ho Lee ${ }^{*}$ \\ *School of Integrative Engineering, Chung-Ang University, Heuseok-dong, Dongjak-Gu, Seoul 06974, \\ South Korea \\ \#E-mail: mhlee7@cau.ac.kr; Tel: +82-2-820-5503; Fax: +82-2-814-2651
}

\begin{abstract}
MXene nanosheets of type $\mathrm{Ti}_{3} \mathrm{C}_{2} \mathrm{~T}_{x}$ were modified with $\beta$-hydroxybutyrate dehydrogenase and then used as a biosensor for amperometric sensing of $\beta$-hydroxybutyrate. The MXene and the nanocomposite were characterized by X-ray photoelectron spectroscopy, field-emission scanning electron microscopy, X-ray diffraction, and Fourier-transform infrared spectroscopy. The MXene has a layered structure and proved to be an excellent immobilization matrix that provides good compatibility with the enzyme $\beta$-hydroxybutyrate dehydrogenase. The MXene based biosensor, best operated at a potential of $-0.35 \mathrm{~V}(\mathrm{vs}$. $\mathrm{Ag} / \mathrm{AgCl}$ ), displays a wide linear range $(0.36$ to $17.9 \mathrm{mM})$, a sensitivity of $0.480 \mu \mathrm{A} \mathrm{mM}^{-1} \mathrm{~cm}^{-2}$, and a low detection limit $(45 \mu \mathrm{M})$. The biosensor was successfully applied to the determination of $\beta$-hydroxybutyrate in (spiked) real serum samples
\end{abstract}

Keywords: MXene, $\mathrm{Ti}_{3} \mathrm{C}_{2} \mathrm{~T}_{\mathrm{x}}, \mathrm{Ti}_{3} \mathrm{AlC}_{2}, \beta$-Hydroxybutyrate, biosensor, amperometric sensor, ketone bodies, diabetic ketosis, diabetic ketoacidosis 


\section{Introduction}

Diabetic ketosis is the term used to denote the condition of the body of diabetes patients with slightly increased concentration of ketone bodies. At diabetic ketosis, the normal range of acidity and alkalinity can be maintained by the body itself. When ketone bodies further increase beyond the body's regulating ability, metabolic acidosis can occur, and the condition refers to diabetic ketoacidosis occur. During fatal diabetic ketoacidosis, blood $\beta$-HBA levels can reach up to $20 \mathrm{mM}[1]$. Therefore, determination of $\beta$-HBA is crucial in the diagnosis and treatment of diabetic ketoacidosis/diabetic ketosis. The reported incidence of diabetic ketoacidosis is above $20 \%$ in patients of age group 65 years or above[2]. Delays in the diagnosis of diabetic ketoacidosis are more often associated with the risk of morbidity and mortality[3]. The diagnosis of diabetic ketoacidosis is not easy because $1-8 \%$ of the patients are ketoacidotic without being hyperglycemic $[3,4]$. The commonly available Bayer Ketostix reagent strips in the market measure the less prominent urinary acetoacetate and often produce false-negative results[5]. Also, laboratory measurements of $\beta$-HBA take too long and are not very useful in the emergency diagnosis of diabetic ketoacidosis[5]. Although the blood and urine ketone can reveal the concentration of ketone bodies in the body, however, because of the direct correlation of ketone bodies with $\beta$-HBA[6], the serum ketone was preferred as the biochemical parameter for the diagnosis of diabetic ketosis/diabetic ketoacidosis. In a typical clinical application, diabetic ketosis/diabetic ketoacidosis is diagnosed based on two biochemical parameters, which are blood ketone $>3 \mathrm{mM}$ and blood glucose concentration > $13.9 \mathrm{mM}[7]$. It is essential to measure the ketone concentration of diabetic patients with a blood glucose concentration exceeding $13.9 \mathrm{mM}$ to diagnose diabetic ketosis / diabetic ketoacidosis.

Since the discovery of graphene with outstanding properties, two-dimensional (2D) materials have attracted research interest in materials science[8,9]. The new family of $2 \mathrm{D}$ materials known as MXenes[10,11] consist of transition metal carbides, nitrides, and carbonitrides, and are synthesized from the layered type of carbides known as MAX phases[11] by the selectively etching the "A" layers, resulting in graphene-like morphology[12]. MXenes attracted research interest due to the metallic conductivity, hydrophilic surfaces, large surface area, layered structure, environmentally friendly characteristics, and remarkable chemical stability[13-15]. The hydrophilic surface allows easy dispersion of Mxene in aqueous solutions. The higher conductivity of Mxene compared to solution-processed graphene[16] and the possibility of easy functionalization during the etching process itself made them a promising alternative to graphene. MXenes have already been explored as supercapacitors[13], electrode materials for Li-ion batteries[17], and biosensors[18-20]. MXene undergoes irreversible oxidation to $\mathrm{TiO}_{2}$ in the positive potential window[21] and remained a challenge for biosensor applications. The proposed sensor utilizes $\beta$ hydroxybutyrate dehydrogenase $(\beta-\mathrm{HBD})$ decorated $M X e n e$ nanosheets for the selective and sensitive determination of ketone body $\beta$-HBA at the negative potential $-0.35 \vee(\mathrm{vs}$. $\mathrm{Ag} / \mathrm{AgCl}$ ). To the best of our knowledge, MXene or MXene nanocomposites have never been used for the biosensing of $\beta$-HBA. 


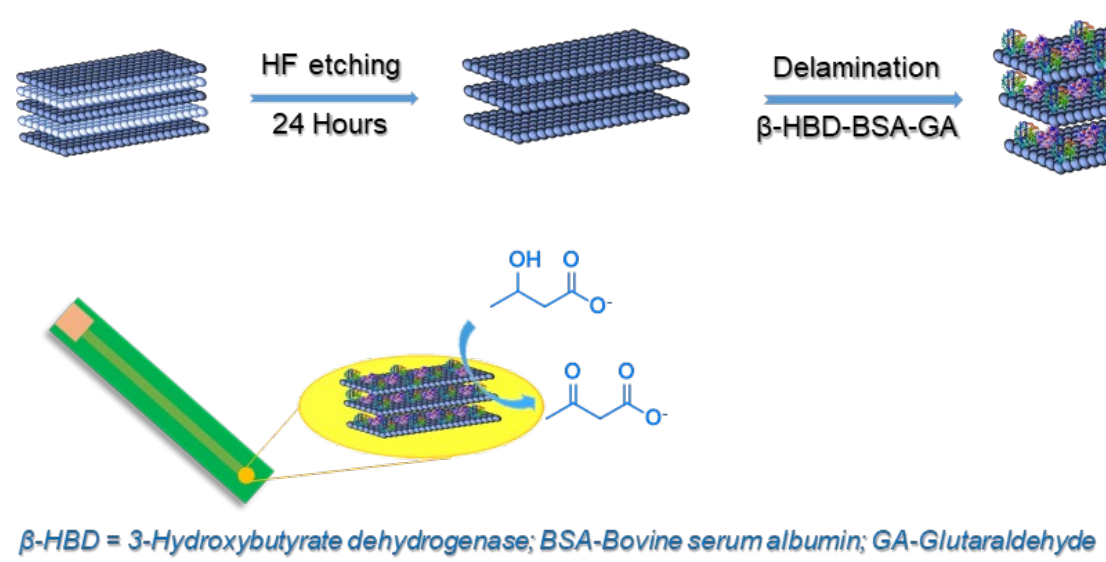

Fig. 1 Schematic representation of the synthesis and decoration of MXene 2D sheets with $\beta$ hydroxybutyrate dehydrogenase for the amperometric determination of $\beta$-Hydroxybutyric acid

\section{Experimental}

\section{Chemicals and reagents}

Titanium aluminium carbide powder $\left(\mathrm{Ti}_{3} \mathrm{AlC}_{2}, 99.9 \%\right)$ was purchased from Shanghai Xinglu Chemical Technology Co., Ltd (https://www.xingluchemical.com), Hydrofluoric acid (ACS reagent, 48\%), Bovine Serum Albumin ( $\geq 98 \%$ ), Hexaammineruthenium(III) chloride $(98 \%), \beta$-hydroxybutyrate dehydrogenase (from pseudomonas lemoignei), Glutaraldehyde solution, Potassium hexacyanoferrate(II) trihydrate and Potassium hexacyanoferrate(III) were purchased from Sigma-Aldrich (https://www.sigmaaldrich.com). $\beta$ Hydroxybutyric acid was procured from the Tokyo chemical industry (https://www.tcichemicals.com/en/kr). Phosphate buffer saline (PBS) tablets, Sodium chloride, and Potassium chloride (99\%) were obtained from Sigma-Aldrich. Gold-printed circuit board (Au-PCB, $2 \mathrm{~mm}$ dia.) electrode (Supporting information) was fabricated in Chung-Ang University, Seoul. Spiral Pt counter electrode and silver/silver chloride $(\mathrm{Ag} / \mathrm{AgCl})$ reference electrodes were purchased from BASi (https://www.basinc.com). All the chemical reagents used in this experiment were of analytical grade and were used without further purification. All the reagents and buffers were prepared using the deionized water obtained from ACE water purification system with resistance not less than $18.2 \mathrm{M} \Omega \mathrm{cm}$.

\section{Material Characterization}

The $\mathrm{Ti}_{3} \mathrm{C}_{2} \mathrm{~T}_{x}$ MXene was synthesized by adopting a previously reported method[22] (Supporting information). The synthesized $\mathrm{Ti}_{3} \mathrm{C}_{2} \mathrm{~T}_{x} \mathrm{MXene}$ was characterized by Field- emission scanning electron microscopy (FE-SEM), X-ray diffraction (XRD), X-ray photoelectron spectroscopy (XPS), and Fouriertransform infrared spectroscopy (FT-IR) and. FE-SEM was performed on Carl Zeiss SIGMA Field emission scanning electron microscope. XRD patterns were recorded on a Bruker-AXS New D8-Advance X-ray 
diffractometer using CuKa radiation of wavelength $\lambda=0.15418 \mathrm{~nm}$ at $40 \mathrm{kV}$ and $40 \mathrm{~mA}$. XPS was performed on the Thermo Fisher Scientific K-alpha+ X-ray photoelectron spectroscope, and the deconvolution of the spectra was performed using XPSPEAK 41 software. FT-IR spectra were recorded on Bruker ALPHA II FT-IR Spectrometer using the Attenuated Total Reflection (ATR) module. All the electrochemical measurements were performed using a $\mathrm{CHI} 660 \mathrm{E}$ electrochemical workstation ( $\mathrm{CH}$ Instruments, Inc). A standard three-electrode cell, comprising of custom made $2 \mathrm{~mm}$ diameter Au-PCB working electrode, an $\mathrm{Ag} / \mathrm{AgCl}(3 \mathrm{M} \mathrm{NaCl})$ reference electrode and a counter electrode (Platinum spiral wire) were used for electroanalysis. Phosphate buffered saline (PBS, $0.1 \mathrm{M}$ ) of $\mathrm{pH} 7.4$ was used as the supporting electrolyte in electrochemical experiments unless otherwise noted.

\section{Preparation of the enzyme electrode}

To investigate the electrochemical behavior of $\mathrm{Ti}_{3} \mathrm{C}_{2} \mathrm{~T}_{x} / \beta$-hydroxybutyrate dehydrogenase nanocomposite, the enzyme electrode was assembled (Fig. 1). BSA was well reported to stabilize the enzyme through hydrophobic interactions[23,24]. In this work, we have used BSA to stabilize the enzyme by linking to the enzyme through glutaraldehyde. Briefly, an Au-PCB electrode was sonicated in acetone, ethanol, and water successively. The cleaned Au-PCB was then dried in a purified nitrogen stream. The enzyme electrode was prepared by a drop-casting method. Firstly, to a $10 \mu \mathrm{L}$ suspension of $5 \mathrm{mgmL}^{-1} \mathrm{Ti}_{3} \mathrm{C}_{2} \mathrm{~T}_{\mathrm{x}}, 10 \mu \mathrm{L}$ of $\beta$ hydroxybutyrate dehydrogenase $\left(0.2 \mathrm{mg} \mathrm{\mu L}^{-1}, 318\right.$ units) was added and gentle sonicated for $10 \mathrm{~min}$. To the resulting MXene- $\beta$-hydroxybutyrate dehydrogenase composite, $10 \mu \mathrm{L}$ of $2.0 \%$ Bovine Serum Albumin (BSA), $10 \mu \mathrm{L}$ of $5 \mathrm{mM} \mathrm{NAD}^{+}$and $15 \mu \mathrm{L} 2.5 \%$ of glutaraldehyde (GA) was added. The suspension was then sonicated for 3 minutes. Finally, $3 \mu \mathrm{L}$ of the mixture was applied to the surface of an Au-PCB, which was previously modified with $3 \mu \mathrm{L}$ of $1 \mathrm{mM} \mathrm{Ru}\left(\mathrm{NH}_{3}\right)_{6}{ }^{3+}$ to prepare the Au-PCB/Ru/MXene- $\beta$-HBD-NAD ${ }^{+}-\mathrm{GA}-$ $\mathrm{BSA}$ electrode and then stored at $4{ }^{\circ} \mathrm{C}$ in the refrigerator before using. In the control experiment, $\mathrm{Au}-$

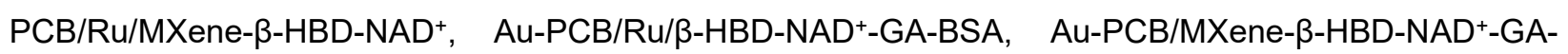
BSA, Au-PCB/Ru/MXene- $\beta-H B D-N A D^{+}-G A-B S A ~(5 \%)$ and Au-PCB/Ru/MXene- $\beta-H B D-N A D^{+}-G A$ (5\%)BSA were prepared using the procedure mentioned above. Before the electrochemical measurements, all the prepared electrodes were immersed in $\mathrm{pH} 7.4(0.1 \mathrm{M})$ PBS for $30 \mathrm{~min}$ to remove any residual components and unbound enzymes. The enzyme electrode was then optimized for optimal performance (Supporting information).

\section{Results and discussions}

\section{Characterization of $\mathrm{Ti}_{3} \mathrm{C}_{2} \mathrm{~T}_{\mathbf{x}}$ MXene}

The morphology of the synthesized $\mathrm{Ti}_{3} \mathrm{C}_{2} \mathrm{~T}_{x}$ MXene was analyzed using FE-SEM. Fig. 2 shows the FE-SEM image of the MAX phase $\mathrm{Ti}_{3} A \mathrm{Al}_{2}$, the synthesized MXene $\mathrm{Ti}_{3} \mathrm{C}_{2} \mathrm{~T}_{x}$, and the $\beta-H B D-M X e n e$ nanocomposite. From Fig. 2b, and Fig. 2c, the layered morphology of the synthesized MXene resembled graphene[25] with the thickness of the individual layers $\sim 35 \mathrm{~nm}$. The enzyme loading on the MXene is observed in Fig. $2 \mathrm{~d}$. The BSA with excellent biocompatibility makes the nanocomposite stable for long-term usage. The layered structure of the MXene with more inner space can immobilize more enzyme. Together with BSA, it provides 
a protective microenvironment for the $\beta-H B D$ to retain bioactivity. Fig. S5a depicts the XRD patterns of the MAX phase $\mathrm{Ti}_{3} \mathrm{AlC}_{2}$ and the synthesized $\mathrm{Ti}_{3} \mathrm{C}_{2} \mathrm{~T}_{x}$ MXene. The XRD pattern of the HF etched $\mathrm{Ti}_{3} \mathrm{C}_{2} \mathrm{~T}_{x} \mathrm{MXene}$ shows broadened peaks of (002), (004), and (0010) with low intensity and a shift to lower angles compared to the un-treated MAX phase. The obtained spectra for the synthesized MXene is consistent with the simulated spectra for $\mathrm{Ti}_{3} \mathrm{C}_{2}(\mathrm{OH})_{2}$ [22]. The presence of hydroxyl groups on the prepared MXene is also confirmed by FT-IR spectroscopy. The FT-IR spectrum of the prepared MXene $\mathrm{Ti}_{3} \mathrm{C}_{2} \mathrm{~T}_{x}$ is shown in Fig. S6. The peak around $3700 \mathrm{~cm}^{-1}$ and the sharp peak around $1389 \mathrm{~cm}^{-1}$ indicates the presence of free hydroxyl groups. The peak at $1051 \mathrm{~cm}^{-1}$ indicates C-O stretching [26,27]. The peak at $651 \mathrm{~cm}^{-1}$ may be assigned to the stretching of the Ti-O bond [28]

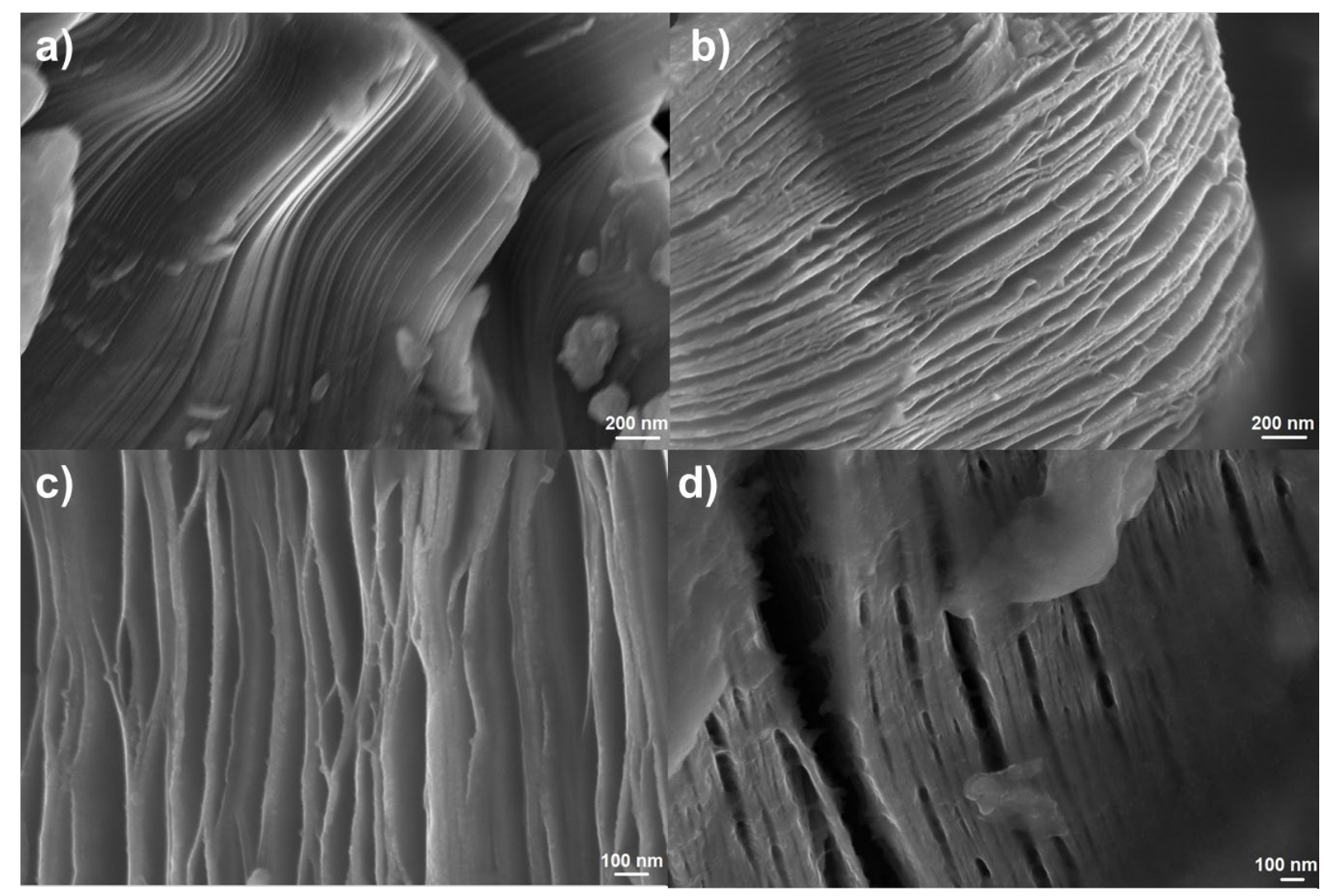

Fig. 2 a) FE-SEM images of the MAX phase $\mathrm{Ti}_{3} \mathrm{AIC}_{2}$, b) $\mathrm{Ti}_{3} \mathrm{C}_{2} \mathrm{~T}_{\mathrm{x}}, \mathrm{c}$ ) Higher resolution image of $\mathrm{Ti}_{3} \mathrm{C}_{2} \mathrm{~T}_{\mathrm{x}}$ and d) $\mathrm{Ti}_{3} \mathrm{C}_{2} \mathrm{~T}_{x}-\beta-\mathrm{HBD}-\mathrm{NAD}{ }^{+}-\mathrm{GA}-\mathrm{BSA}$ nanocomposite

The XPS survey spectrum of the synthesized MXene confirmed the presence of elements Ti, C, F, and O (Fig. S5b, Supporting information). The core-level spectrum of Ti $2 p$ region, as shown in Fig. S5c, shows the majority of the $\mathrm{Ti}$ species as $\mathrm{Ti}^{+}, \mathrm{Ti}^{2+}, \mathrm{Ti}^{3+}$ due to the surface terminations $\mathrm{C}-\mathrm{Ti}-\mathrm{O}_{\mathrm{x}}, \mathrm{C}-\mathrm{Ti}-(\mathrm{OH})_{\mathrm{x}}, \mathrm{C}-\mathrm{Ti}-\mathrm{F}_{\mathrm{x}}$, and $\mathrm{Ti}_{3} \mathrm{C}_{2} \mathrm{OH}-\mathrm{H}_{2} \mathrm{O}[29]$. Ti-F bond belongs to the surface termination $\mathrm{C}-\mathrm{Ti}-\mathrm{F}_{\mathrm{x}}$. The formation of $\mathrm{Ti}_{3} \mathrm{C}_{2} \mathrm{~T}_{\mathrm{x}}$ with oxygen-containing terminations is evident from the presence of the $\mathrm{Ti}-\mathrm{C}$ and $\mathrm{Ti}-\mathrm{O}$ bonds. The core-level spectrum of $\mathrm{O} 1 \mathrm{~s}$ (Fig. S5d, Supporting information) is fitted by three peaks, assigned to the surface terminations $\mathrm{C}-\mathrm{Ti}-\mathrm{O}_{x}, \mathrm{C}-\mathrm{Ti}-(\mathrm{OH})_{x}$ and adsorbed $\mathrm{H}_{2} \mathrm{O}$. The fitted peaks of the $\mathrm{F}$ 1s region (Fig. S5e, 
Supporting information) are assigned to Ti-F and C-F bonds. The core-level spectrum of the $\mathrm{C} 1 \mathrm{~s}$ region is fitted by four peaks (Fig. S5f, Supporting information). The largest peak located $\sim 282.0 \mathrm{eV}$ corresponds to $\mathrm{C}-\mathrm{Ti}-\mathrm{T}_{\mathrm{x}}$. The two other peaks at $284.8 \mathrm{eV}$ and $286.6 \mathrm{eV}$ assigned to the $\mathrm{C}-\mathrm{C}$ and $\mathrm{C}-\mathrm{O}$ bonds respectively. The weak peak at $288.9 \mathrm{eV}$ is assigned to the groups $\mathrm{O}-\mathrm{C}=\mathrm{O}$ and/or $\mathrm{C}-\mathrm{F}$ [30-32].

\section{Characterization of the modified electrodes}

FT-IR spectroscopy is an effective tool for exploring the secondary structure of the enzymes[33]. The successful immobilization of the enzyme composite on the electrode surface is also evaluated by the FTIR spectroscopy. As shown by the FT-IR spectrum of the enzyme-modified electrode in Fig. S7, the amide I band $\left(1700-1600 \mathrm{~cm}^{-1}\right)$ results from $\mathrm{C}=\mathrm{O}$ stretching vibration of the peptide bonds in the protein backbone. The amide II band $\left(1620-1500 \mathrm{~cm}^{-1}\right)$ is caused by the combination of $\mathrm{C}-\mathrm{N}$ stretching and $\mathrm{N}-\mathrm{H}$ bending.

The electroactive surface area of the electrodes was calculated at each step of the Au-PCB modification process to observe the effect of modification on the electroactive surface area (Fig. S8, Supporting information). The electroactive surface area remained nearly the same after the modification of Au-PCB with $\mathrm{Ru}^{3+}$. However, after modification with the enzyme composite, much decrease in the electroactive surface area was observed (Supporting information).

Cyclic voltammetry is a powerful tool to optimize the sensor parameters. Therefore, we performed cyclic voltammetry on four electrodes, Au-PCB/Ru/MXene- $\beta-H B D-N A D^{+}-G A-B S A, A u-P C B / R u / M X e n e-\beta-$ HBD-NAD+-BSA, Au-PCB/Ru/ $\beta-H B D-N A D^{+}-G A-B S A$, and Au-PCB/MXene- $\beta-H B D-N A D^{+}-G A-B S A$. As shown in Fig. 3a, Au-PCB/Ru/MXene- $\beta-H B D-N A D^{+}-G A-B S A$ electrode shows a characteristic reduction peak around $-0.35 \mathrm{~V}$ in the presence of $\beta$-HBA, which increased with increasing concentration of $\beta$-HBA (Fig. 3b). The reduction current for the electrode Au-PCB/Ru/ $\beta-H B D-N A D^{+}-G A-B S A$ without MXene loading is very poor, showing that MXene can effectively immobilize the enzyme $\beta$-HBD over the nanolayers. The characteristic reduction peak around $-0.35 \mathrm{~V}$ is absent for Au-PCB/MXene- $\beta$-HBD-NAD+-GA-BSA showing that $\mathrm{Ru}(\mathrm{III}) / \mathrm{Ru}(\mathrm{II})$ redox couple is crucial in the functioning of the sensor, supporting the cascade of reactions at the electrode/electrolyte interface (Fig. S9, Supporting information). The $\beta$-HBD oxidized $\beta$ HBA to acetoacetate with the concomitant reduction of $\mathrm{NAD}^{+}$to $\mathrm{NADH}$. The $\mathrm{NADH}$ is then re-oxidized back to $\mathrm{NAD}^{+}$by the redox mediator Hexaammineruthenium(III) chloride and the current generated in the process is directly proportional to the concentration of $\beta$-HBA. 

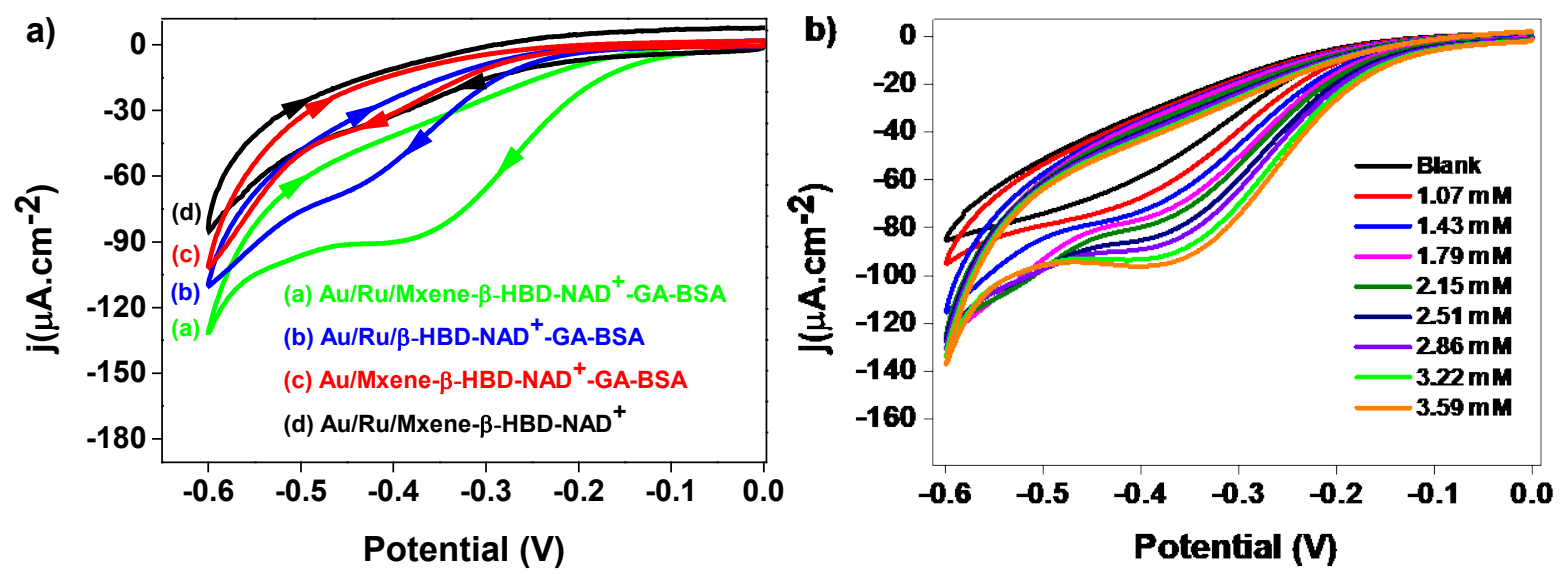

Fig. 3 a) Cyclic voltammograms of Au-PCB/MXene-- $3-H B D-N A D^{+}-G A-B S A$ (red line), Au-PCB/Ru/MXene$\beta-H B D-N A D^{+}$(black line), Au-PCB/Ru/ß-HBD-NAD+-GA-BSA (blue line) and Au-PCB/Ru/MXene- $\beta-H B D-$ NAD ${ }^{+}-G A-B S A$ (green line) in the presence of $3.6 \mathrm{mM} \beta-H B A$, b) Cyclic voltammograms of Au$P C B / R u / M X e n e-\beta-H B D-N A D^{+}-G A-B S A$ in the presence of varying concentrations of $\beta-H B A$. The experiments were performed in in $0.1 \mathrm{M} \mathrm{PBS}(\mathrm{pH} 7.4)$ at a scan rate of $50 \mathrm{mV} \cdot \mathrm{s}^{-1} \mathrm{vs} . \mathrm{Ag} / \mathrm{AgCl}(3 \mathrm{M} \mathrm{NaCl})$.
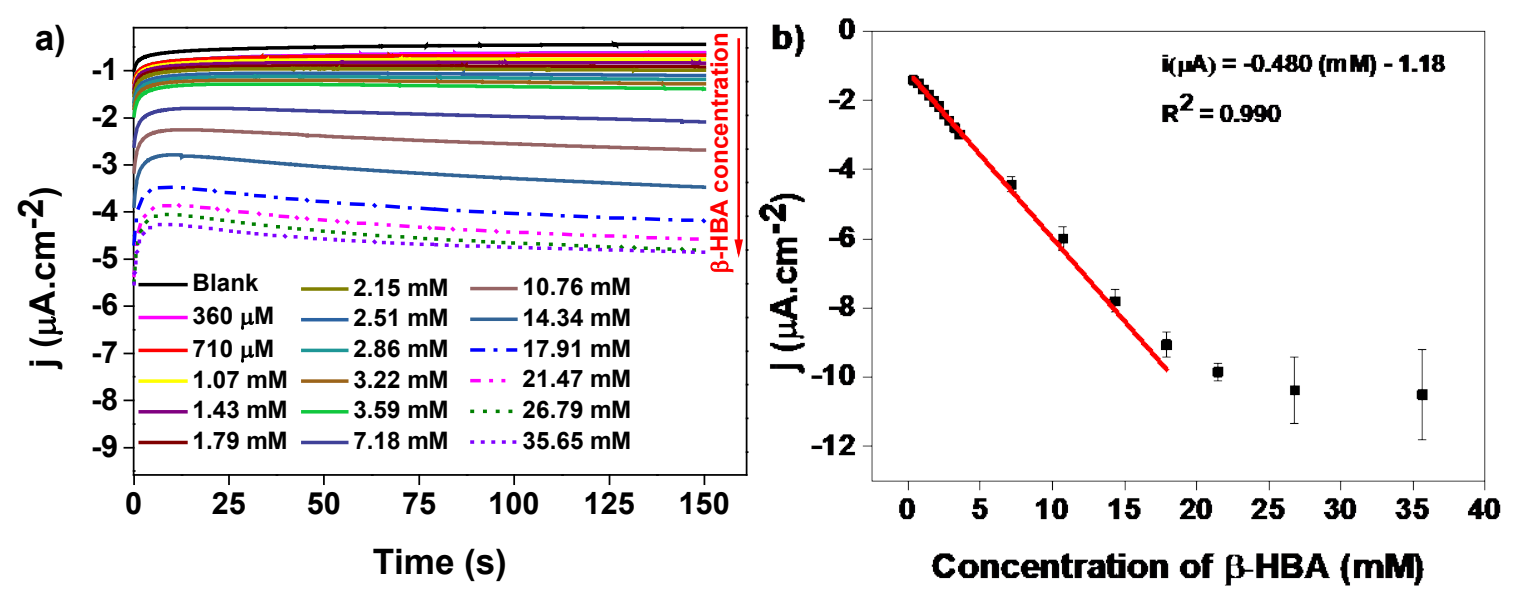

Fig. 4 a) The amperometry i-t curve obtained at the Au-PCB/Ru/MXene- $\beta$-HBD-NAD+-GA-BSA electrode at an applied potential of $-0.35 \mathrm{~V}$ vs. $\mathrm{Ag} / \mathrm{AgCl}(3 \mathrm{M} \mathrm{NaCl})$ in $\mathrm{PBS} \mathrm{pH} 7.4 \mathrm{~b})$ The corresponding linear calibration plot for the amperometric determination of $\beta$-HBA $(n=3)$.

\section{Biosensor performance}

The biosensor performance for the determination of $\beta$-HBA on the Au-PCB/Ru/MXene- $\beta$-HBD-NAD+-GABSA electrode was investigated by amperometry. Fig. 4a corresponds to the amperometric responses of the Au-PCB/Ru/MXene- $\beta-H B D-N A D^{+}-G A-B S A$ electrode at $-0.35 \mathrm{~V}$ after the addition $\beta$-HBA in stirred PBS $(\mathrm{pH}$ 7.4). A well-defined linear relationship between the current and the $\beta-H B A$ concentration was observed. The calibration plot (Fig. 4b) showed a linear range from $360 \mu \mathrm{M}$ to $17.91 \mathrm{mM}\left(\mathrm{R}^{2}=0.990\right)$ with a sensitivity 
of $0.480 \mu \mathrm{A} \mathrm{mM}^{-1} \mathrm{~cm}^{-2}$. The limits of detection (LOD) was calculated using the equation: $\mathrm{LOD}=3 \sigma / \mathrm{m}$, where " $\sigma$ " is the standard deviation of the reduction current from the blank experiment $(n=3)$ and " $m$ " is the slope $\left(\mu \mathrm{A} \mathrm{mM}{ }^{-1}\right)$ of the calibration plot. The LOD was calculated to be $44.5 \mu \mathrm{M}$. A comparison of the electrochemical performance of various $\beta$-HBA biosensors was listed in Table. S1. It was clear that the performance of Au-PCB/Ru/MXene- $\beta-H B D-N A D^{+}-G A-B S A$ was superior to most of the reported $\beta-H B A$ sensors. The $\mathrm{Ti}_{3} \mathrm{C}_{2} \mathrm{~T}_{\mathrm{x}}$ layers and $\mathrm{BSA}$ provide a suitable environment for the $\beta$-HBD to retain its activity and stability, also helpful in entrapping the substrate. This leads to increased effective interaction between the substrate and the redox protein leading to improved performance [34,35].

The $\mathrm{K}_{\mathrm{m}}$ value of the Au-PCB/Ru/MXene- $\beta$-HBD-NAD+-GA-BSA electrode was calculated by using the modified Line weaver-Burk equation[36] proposed by Kamin and Wilson for electrochemical applications.

$$
\frac{1}{\mathrm{I}_{\mathrm{ss}}}=\left(\frac{\mathrm{K}_{\mathrm{m}}}{\mathrm{I}_{\max }}\right)\left(\frac{1}{\mathrm{C}}\right)+\frac{1}{\mathrm{I}_{\max }}
$$

Where $I_{s s}$ is the steady-state current obtained after the addition of substrate with concentration $C, I_{\max }$ is the maximum current observed on the enzymatic electrode under the conditions of substrate saturation. A plot of $1 / \mathrm{I}_{\mathrm{ss}}$ vs. $1 / \mathrm{C}$ will give a straight line with the slope equal to $\mathrm{K}_{\mathrm{m}} / \mathrm{I}_{\max }$, and an intercept equal to $\mathrm{I} / \mathrm{I}_{\max }$. The $\mathrm{K}_{\mathrm{m}}$ value for the Au-PCB/Ru/MXene-B-HBD-NAD+-GA-BSA electrode was estimated to be $8.7 \mathrm{mM}$ (Fig. $S 10$, Supporting information). This value was higher than the previously reported[37], indicating a lower affinity towards $\beta$-HBA, suitable for the determination of higher concentrations of $\beta$-HBA.

\section{Stability and reproducibility}

The stability of the Au-PCB/Ru/MXene- $\beta-H B D-N A D^{+}-G A-B S A$ electrode was investigated by chronoamperometry. Electrode fouling during the amperometric experiment may affect the performance of the biosensor and lead to a reduction of the amperometric signal. To observe the electrode fouling effects, $1 \mathrm{mM} \beta$-HBA was added to a stirred 0.1 M PBS ( $\mathrm{pH} 7.4$ ) solution, and the current change over time on the Au-PCB/Ru/MXene- $\beta$-HBD-NAD+-GA-BSA electrode was measured (Fig. S11, Supporting information). The current remained constant after the steady-state and lasted longer than 80 min without significant change. Based on this data, we can conclude that electrode fouling did not occur from the oxidation products of $\beta$-HBA. The long-term stability of the biosensor was also evaluated for estimating the performance of the biosensor. The long-term stability was studied by storing the biosensor dry at $4{ }^{\circ} \mathrm{C}$ and examining the current response after 7 , and 30 days. The biosensor retained about $97.08 \%$ of its initial response to $\beta$-HBA after 7 days and $93.20 \%$ after 30 days, demonstrating excellent long-term stability (Fig. $\mathrm{S} 12$, Supporting information). The excellent stability may be attributed to the layered structure of MXene with more inner space in between the layers for the enzyme and BSA, which can provide the enzyme with a protective microenvironment to retain the bioactivity on long-term use[38]. The reproducibility of the biosensor was investigated by fabricating four biosensors independently under the same conditions and 
checking the performance for $\beta$-HBA. The prepared electrodes independently gave an R.S.D. of $5.89 \%$ for the determination of $3.6 \mathrm{mM} \beta-\mathrm{HBA}$, indicating acceptable electrode-to-electrode reproducibility.

\section{Selectivity of the $\beta$-HBA biosensor}

Selectivity is an essential parameter in the practical use of any biosensors. The selectivity of the MXene- $\beta$ HBD based biosensor was evaluated with twice the concentration of typical interfering substances in serum such as glucose (GI), uric acid (UA), and ascorbic acid (AA) by using the amperometric current-time method. As shown in Fig. S13, the tested substances produced only a seemingly negligible reduction current, probably due to the dissolved Oxygen in the analytes. This result might be attributed to the intrinsic selectivity of the enzyme $\beta$-HBD towards its substrate $\beta$-HBA.

\section{Analysis of real samples}

In order to evaluate the analytical utility of the electrode in practice, the Au-PCB/Ru/MXene- $\beta-H B D-N A D^{+}-$ GA-BSA was applied for the determination of spiked $\beta$-HBA from real serum samples. Three serum samples were collected and standard $\beta$-HBA was added to the serum samples. The signals were recorded as amperometric i-t curves. The recoveries of added analyte were evaluated from the reduction current. As shown in Table. S2, the percentage of recovery of the $3 \mathrm{mM}, 4 \mathrm{mM}$, and $5 \mathrm{mM}$ spiked $\beta$-HBA from the three different samples were $104 \%, 103.5 \%$, and $101.8 \%$ respectively with the RSD in the range of $2.1-3.2 \%$. The results confirmed that it is possible to determine the concentration of $\beta$-HBA from real samples using the reported method.

\section{Conclusions}

A novel $\beta$-hydroxybutyrate dehydrogenase modified $\mathrm{Ti}_{3} \mathrm{C}_{2} \mathrm{~T}_{x}$ MXene nanocomposite has been synthesized through a simple synthetic route and subsequently used to fabricate a biosensor for the determination of $\beta$ HBA from serum samples. The layer-like morphology of the $\mathrm{Ti}_{3} \mathrm{C}_{2} \mathrm{~T}_{\times} \mathrm{MXene}$ was beneficial to immobilize and entrap the enzyme, thereby leading to increased stability and improved performance of the sensor. The excellent biocompatibility of BSA on the nanocomposite surface provided a microenvironment suitable for the $\beta-H B D$ to retain bioactivity and stability for a long time, as evident from the long-term stability of the sensor. Due to the above reasons, the prepared biosensors displayed a low detection limit of $44.5 \mu \mathrm{M}$, with a wide linear range of $360 \mu \mathrm{M}-17.91 \mathrm{mM}$ for $\beta$-HBA. This study also indicates that $\mathrm{Ti}_{3} \mathrm{C}_{2} \mathrm{~T}_{\mathrm{x}} \mathrm{MXene}$ can be used as a biocompatible matrix for the construction of direct electrochemical biosensors. Though the reported method is advantageous to the previously reported literature methods in many aspects, research in this area still needs much improvement. The sensitivity of the electrode may be improved further and the possibility of inclusion of nanoparticles in the enzyme nanocomposite will be considered in future work. 


\section{Compliance with ethical standards}

\section{Conflict of interest}

The authors report no conflicts of interest.

ORCID

Dr. Aneesh Koyappayil: http://orcid.org/0000-0001-7872-8489

Sachin Ganpat Chavan: http://orcid.org/0000-0002-3052-5524

Dr. Mohsen Mohammadniaei: http://orcid.org/0000-0002-4773-2888

Anna Go: https://orcid.org/0000-0003-0054-6188

Sei Young Hwang: http://orcid.org/0000-0003-0808-8628

Prof. Min-Ho Lee: http://orcid.org/0000-0002-7028-4745 


\section{References}

1. Cahill Jr GF, Veech RL (2003) Ketoacids? Good medicine? Transactions of the american clinical and climatological association 114:149

2. Lebovitz HE (1995) Diabetic ketoacidosis. Lancet 345:767-772. https://doi.org/10.1016/s0140$\underline{6736(95) 90645-2}$

3. Singh RK, Perros P, Frier BM (1997) Hospital management of diabetic ketoacidosis: are clinical guidelines implemented effectively? Diabet Med 14:482-486. https://doi.org/10.1002/(SICI)10969136(199706)14:6<482::AID-DIA371>3.0.CO;2-A

4. Jenkins D, Close C, Krentz A, Nattrass M, Wright A (1993) Euglycaemic diabetic ketoacidosis: does it exist? Acta diabetologica 30:251-253. https://doi.org/10.1007/BF00569937

5. Byrne HA, Tieszen KL, Hollis S, Dornan TL, New JP (2000) Evaluation of an electrochemical sensor for measuring blood ketones. Diabetes Care 23:500-503. https://doi.org/10.2337/diacare.23.4.500

6. Cao X, Zhang XJ, Xian Y, Wu JC, Bao MJ, Yang Y, Zhu XJ, Zhang L, Liu LM, Yang Y, Zhou H, Li PQ (2014) The diagnosis of diabetic acute complications using the glucose-ketone meter in outpatients at endocrinology department. International Journal of Clinical and Experimental Medicine 7:5701-5705 7. Guo JH, Huang XW, Ma X (2018) Clinical identification of diabetic ketosis/diabetic ketoacidosis acid by electrochemical dual channel test strip with medical smartphone. Sensors and Actuators B-Chemical 275:446-450. https://doi.org/10.1016/i.snb.2018.08.042

8. Schedin F, Geim AK, Morozov SV, Hill EW, Blake P, Katsnelson MI, Novoselov KS (2007) Detection of individual gas molecules adsorbed on graphene. Nat Mater 6:652-655. https://doi.org/10.1038/nmat1967 9. Geim AK, Novoselov KS (2010) The rise of graphene. In: Nanoscience and Technology: A Collection of Reviews from Nature Journals. World Scientific, pp 11-19

10. Shein IR, Ivanovskii AL (2013) Graphene-like nanocarbides and nanonitrides of d metals (MXenes): synthesis, properties and simulation. Micro \& Nano Letters 8:59-62.

https://doi.org/10.1049/mnl.2012.0797

11. Naguib M, Kurtoglu M, Presser V, Lu J, Niu J, Heon M, Hultman L, Gogotsi Y, Barsoum MW (2011)

Two-dimensional nanocrystals produced by exfoliation of $\mathrm{Ti}_{3} \mathrm{AlC}_{2}$. Advanced Materials 23:4248-4253.

https://doi.org/10.1002/adma.201102306

12. Naguib M, Mochalin VN, Barsoum MW, Gogotsi Y (2014) 25th anniversary article: MXenes: a new family of two-dimensional materials. Adv Mater 26:992-1005. https://doi.org/10.1002/adma.201304138 13. Lukatskaya MR, Mashtalir O, Ren CE, Dall'Agnese Y, Rozier P, Taberna PL, Naguib M, Simon P, Barsoum MW, Gogotsi Y (2013) Cation intercalation and high volumetric capacitance of two-dimensional titanium carbide. Science 341:1502-1505. https://doi.org/10.1126/science.1241488

14. Zhao MQ, Ren CE, Ling Z, Lukatskaya MR, Zhang C, Van Aken KL, Barsoum MW, Gogotsi Y (2015) Flexible MXene/carbon nanotube composite paper with high volumetric capacitance. Adv Mater 27:339345. https://doi.org/10.1002/adma.201404140 
15. Ghidiu M, Lukatskaya MR, Zhao MQ, Gogotsi Y, Barsoum MW (2014) Conductive two-dimensional titanium carbide 'clay' with high volumetric capacitance. Nature 516:78-81.

https://doi.org/doi:10.1038/nature13970

16. Dillon AD, Ghidiu MJ, Krick AL, Griggs J, May SJ, Gogotsi Y, Barsoum MW, Fafarman AT (2016) Highly conductive optical quality solution-processed films of 2D titanium carbide. Advanced Functional Materials 26:4162-4168. https://doi.org/10.1002/adfm.201600357

17. Tang Q, Zhou Z, Shen $P$ (2012) Are MXenes promising anode materials for Li ion batteries?

Computational studies on electronic properties and $\mathrm{Li}$ storage capability of $\mathrm{Ti}_{3} \mathrm{C}_{2}$ and $\mathrm{Ti}_{3} \mathrm{C}_{2} \mathrm{X}_{2}(\mathrm{X}=\mathrm{F}, \mathrm{OH})$ monolayer. J Am Chem Soc 134:16909-16916. https://doi.org/10.1021/ja308463r

18. Wang F, Yang C, Duan M, Tang Y, Zhu J (2015) $\mathrm{TiO}_{2}$ nanoparticle modified organ-like $\mathrm{Ti}_{3} \mathrm{C}_{2} \mathrm{MXene}$ nanocomposite encapsulating hemoglobin for a mediator-free biosensor with excellent performances.

Biosens Bioelectron 74:1022-1028. https://doi.org/10.1016/i.bios.2015.08.004

19. Liu H, Duan CY, Yang CH, Shen WQ, Wang F, Zhu ZF (2015) A novel nitrite biosensor based on the

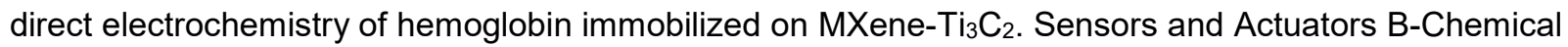
218:60-66. https://doi.org/10.1016/j.snb.2015.04.090

20. Rakhi R, Nayak P, Xia C, Alshareef HN (2016) Novel amperometric glucose biosensor based on MXene nanocomposite. Scientific reports 6:36422. https://doi.org/10.1038/srep36422

21. Nayak P, Jiang Q, Mohanraman R, Anjum D, Hedhili MN, Alshareef HN (2018) Inherent electrochemistry and charge transfer properties of few-layered two-dimensional $\mathrm{Ti}_{3} \mathrm{C}_{2} \mathrm{~T}_{\mathrm{x}} \mathrm{MXene}$. Nanoscale 10:17030-17037. https://doi.org/10.1039/c8nr01883a

22. Naguib M, Kurtoglu M, Presser V, Lu J, Niu J, Heon M, Hultman L, Gogotsi Y, Barsoum MW (2011) Two-dimensional nanocrystals produced by exfoliation of $\mathrm{Ti}_{3} \mathrm{AlC}_{2}$. Adv Mater 23:4248-4253. https://doi.org/10.1002/adma.201102306

23. Chang BS, Mahoney RR (1995) Enzyme thermostabilization by bovine serum albumin and other proteins: evidence for hydrophobic interactions. Biotechnol Appl Biochem 22:203-214

24. Gouda MD, Kumar MA, Thakur MS, Karanth NG (2002) Enhancement of operational stability of an enzyme biosensor for glucose and sucrose using protein based stabilizing agents. Biosensors \& Bioelectronics 17:503-507. https://doi.org/10.1016/S0956-5663(02)00021-0

25. Li X, Wang X, Zhang L, Lee S, Dai H (2008) Chemically derived, ultrasmooth graphene nanoribbon semiconductors. Science 319:1229-1232. https://doi.org/10.1126/science.1150878

26. Zhou L, Wu FM, Yu JH, Deng QH, Zhang FA, Wang G (2017) Titanium carbide $\left(\mathrm{Ti}_{3} \mathrm{C}_{2} \mathrm{~T}_{\mathrm{x}}\right) \mathrm{MXene:} \mathrm{A}$ novel precursor to amphiphilic carbide-derived graphene quantum dots for fluorescent ink, light-emitting composite and bioimaging. Carbon 118:50-57. https://doi.org/10.1016/j.carbon.2017.03.023 27. Xu SK, Wei GD, Li JZ, Ji Y, Klyui N, Izotov V, Han W (2017) Binder-free $\mathrm{Ti}_{3} \mathrm{C}_{2} \mathrm{~T}_{x}$ MXene electrode film for supercapacitor produced by electrophoretic deposition method. Chemical Engineering Journal 317:1026-1036. https://doi.org/10.1016/i.cej.2017.02.144 
28. Musić S, Gotić M, Ivanda M, Popović S, Turković A, Trojko R, Sekulić A, Furić K (1997) Chemical and micro structural properties of $\mathrm{TiO}_{2}$ synthesized by sol-gel procedure. Materials Science and Engineering: B 47:33-40 https://doi.org/10.1016/S0921-5107(96)02041-7

29. Ding L, Wei Y, Li L, Zhang T, Wang H, Xue J, Ding LX, Wang S, Caro J, Gogotsi Y (2018) MXene molecular sieving membranes for highly efficient gas separation. Nat Commun 9:155.

https://doi.org/10.1038/s41467-017-02529-6

30. Halim J, Cook KM, Naguib M, Eklund P, Gogotsi Y, Rosen J, Barsoum MW (2016) X-ray photoelectron spectroscopy of select multi-layered transition metal carbides (MXenes). Applied Surface Science 362:406-417. https://doi.org/10.1016/i.apsusc.2015.11.089

31. Wang L, Zhang H, Wang B, Shen C, Zhang C, Hu Q, Zhou A, Liu B (2016) Synthesis and electrochemical performance of $\mathrm{Ti}_{3} \mathrm{C}_{2} \mathrm{~T}_{x}$ with hydrothermal process. Electronic Materials Letters 12:702710. https://doi.org/10.1007/s13391-016-6088-z

32. Han M, Yin X, Wu H, Hou Z, Song C, Li X, Zhang L, Cheng L (2016) Ti3 $\mathrm{C}_{2}$ MXenes with Modified Surface for High-Performance Electromagnetic Absorption and Shielding in the X-Band. Acs Appl Mater Inter 8:21011-21019. https://doi.org/10.1021/acsami.6b06455

33. Jackson M, Mantsch HH (1995) The use and misuse of FTIR spectroscopy in the determination of protein structure. Crit Rev Biochem Mol Biol 30:95-120. https://doi.org/10.3109/10409239509085140 34. Xie Q, Zhao Y, Chen X, Liu H, Evans DG, Yang W (2011) Nanosheet-based titania microspheres with hollow core-shell structure encapsulating horseradish peroxidase for a mediator-free biosensor.

Biomaterials 32:6588-6594. https://doi.org/10.1016/i.biomaterials.2011.05.055

35. Wang F, Yang C, Duan M, Tang Y, Zhu J (2015) $\mathrm{TiO}_{2}$ nanoparticle modified organ-like $\mathrm{Ti}_{3} \mathrm{C}_{2} \mathrm{MXene}$ nanocomposite encapsulating hemoglobin for a mediator-free biosensor with excellent performances.

Biosensors and Bioelectronics 74:1022-1028. https://doi.org/10.1016/j.bios.2015.08.004

36. Kamin RA, Wilson GS (1980) Rotating-Ring-Disk Enzyme Electrode for Biocatalysis Kinetic-Studies and Characterization of the Immobilized Enzyme Layer. Analytical Chemistry 52:1198-1205.

https://doi.org/10.1021/ac50058a010

37. Batchelor MJ, Green MJ, Sketch CL (1989) Amperometric Assay for the Ketone-Body 3Hydroxybutyrate. Analytica Chimica Acta 221:289-294. https://doi.org/10.1016/S0003-2670(00)81965-0 38. Liu H, Duan C, Yang C, Shen W, Wang F, Zhu Z (2015) A novel nitrite biosensor based on the direct electrochemistry of hemoglobin immobilized on $\mathrm{MXene}-\mathrm{Ti}_{3} \mathrm{C}_{2}$. Sensors and Actuators $\mathrm{B}$ : Chemical 218:60-66. https://doi.org/10.1016/j.snb.2015.04.090 